\title{
Pengaruh Temperatur Austenisasi dan Proses Pendinginan Terhadap Strukturmikro dan Sifat Mekanik Baja Paduan 05CCrMnSi
}

\author{
Kharisma Yuko Rasyidy dan Suwarno \\ Departemen Teknik Mesin, Fakultas Teknologi Industri, Institut Teknologi Sepuluh Nopember (ITS) \\ e-mail: suwarno@me.its.ac.id
}

\begin{abstract}
Abstrak-Penelitian ini mencari pengaruh temperatur austenisasi dan proses pendinginan terhadap baja paduan 05CcrMnSi. Baja paduan ditempa terlebih dahulu untuk mengurangi cacat porositas yang diakibatkan oleh proses pengecoran. Perlakuan panas pada penilitian ini meliputi pemanasan spesimen sampai temperatur austenit stabil $\left(800^{\circ} \mathrm{C}, 850^{\circ} \mathrm{C}\right.$, dan $\left.900^{\circ} \mathrm{C}\right)$ dan ditahan selama 1 jam kemudian didinginkan dengan tiga cara yaitu, pendinginan di air, udara, dan dapur. Pengujian terhadap spesimen meliputi pengamatan strukturmikro, pengujian kekerasan, dan ketangguhan impak. Hasil penempaan menunjukkan bahwa intensitas porositas dan ukuran porositas berkurang. Pengamatan strukturmikro menunjukkan bahwa dengan pendinginan di udara ditemukan strukturmikro martensit. Didapatkan strukturmikro perlit dan ferit pada proses pendinginan di dapur sedangkan pada proses pendinginan di air didapatkan strukturmikro martensit dan austenit sisa. Pada pendinginan di air, jumlah austenit sisa mengalami penurunan seiring dengan bertambahnya temperatur austenisasi. Nilai kekerasan tertinggi didapatkan dari proses pendinginan di air, baik pada temperatur austenisasi $800^{\circ} \mathrm{C}$, $850^{\circ} \mathrm{C}$, maupun $900^{\circ} \mathrm{C}$. Sementara itu nilai kekerasan terendah didapatkan oleh proses pendinginan di dapur. Pada ketiga proses pendinginan, tingginya temperatur austenisasi tidak berpengaruh terhadap nilai kekerasan spesimen. Dalam pengujian ketahanan impak, nilai impact strength dimiliki oleh spesimen dengan proses pendinginan di air kemudian diikuti oleh spesimen dengan proses pendinginan dapur dan udara.
\end{abstract}

Kata Kunci-Baja paduan, perlakuan panas, temperatur austenisasi.

\section{PENDAHULUAN}

$\mathrm{P}$ ERKEMBANGAN teknologi yang semakin maju sekarang ini menyebabkan perlu adanya inovasi dalam hal rekayasa material. Rekayasa material ini diharapkan akan meningkatkan sifat mekaniknya. Pertimbangan rekayasa material tidak hanya berdasarkan dari properties material itu sendiri, proses pembuatan material yang ekonomis juga menjadi pertimbangan.

Salah satu proses rekayasa material adalah Thermo Mechanical Control Process (TMCP). Metode ini menggabungkan proses pengecoran, pengerollan, dan perlakuan panas terkendali dalam satu line process sehinga didapatkan material yang diinginkan. Selain itu, T. Sourmail menyatakan dalam penilitiannya pada tahun 2013 bahwa baja tahan aus dapat dibuat dengan proses austempering pada temperatur rendah dan penambahan unsur paduan utama karbon, mangan, silikon, dan kromium [1].

Untuk memperoleh sifat mekanik yang diinginkan, maka diperlukan strukturmikro yang sesuai. Hal tersebut dapat diperoleh melalui proses perlakuan panas dengan cara memanaskan baja mencapai temperatur austenit stabil dan ditahan beberapa menit kemudian didinginkan dengan proses pendinginan tertentu. Maka dari itu, tujuan dari penelitian ini adalah untuk mengetahui pengaruh temperatur austenisasi dan proses pendinginan terhadap strukturmikro dan sifat mekanik baja paduan $05 \mathrm{CCrMnSi}$.

\section{METODOLOGI PENELITIAN}

Penelitian ini menggunakan baja paduan $05 \mathrm{CCrMnSi}$ hasil pengecoran dengan komposisi kimia yang ditunjukkan pada tabel 1. Material ditempa terlebih dahulu untuk mengurangi porositas yang terjadi pada proses pengecoran.

Tabel 1.

Komposisi kimia dari baja paduan 05CCrMnSi

\begin{tabular}{ccccccc}
\hline \hline Material & \multicolumn{7}{c}{ Berat Paduan (\%) } \\
\hline \multirow{2}{*}{ 05CCrMnSi } & $\mathrm{C}$ & $\mathrm{Si}$ & $\mathrm{Mn}$ & $\mathrm{Cr}$ & $\mathrm{Ni}$ & $\mathrm{P}$ \\
& 0.5 & 1.94 & 1.8 & 1.1 & 0.06 & 0.013 \\
\hline \hline
\end{tabular}

Spesimen pada penelitian ini dipanaskan sampai temperatur austenit stabil $800^{\circ} \mathrm{C}, 850^{\circ} \mathrm{C}$, dan $900^{\circ} \mathrm{C}$. Spesimen ditahan dalam dapur selama satu jam pada temperatur austenit stabil. Selanjutnya spesimen didinginkan di air(temperatur ruang), udara, dan dapur. Skema proses perlakuan panas pada penilitian ini ditunjukkan pada gambar 1 .

Untuk mengetahui hasil dari perlakuan panas yang

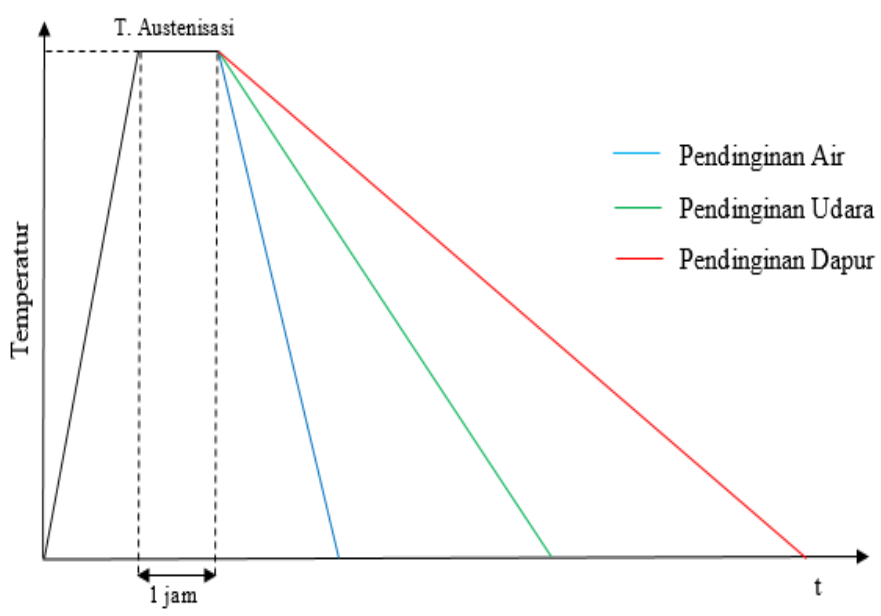

Gambar 1. Skema perlakuan panas.

dilakukan pada spesimen, dilakukan beberapa pengujian yang meliputi pengamatan strukturmikro, pengujian hardness menggunakan metode Rockwell $\mathrm{C}$, dan pengujian ketangguhan impak dengan standar JIS Z 2242. 


\section{ANALISA DAN PEMBAHASAN}

\section{A. Analisa dan Pembahasan Pengamatan Strukturmikro}

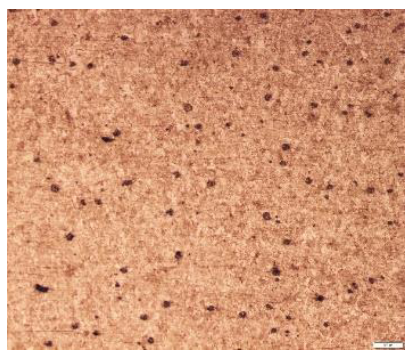

(a)

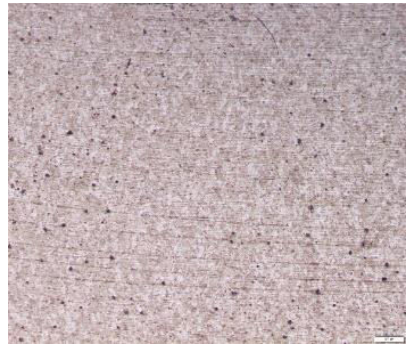

(b)
Gambar 2. Perbandingan porositas pada spesimen (a) as cast dan (b) as forged.

Sebelum diberi perlakuan panas spesimen melewati proses forging terlebih dahulu. Proses forging ini bertujuan untuk mengurangi cacat porositas yang ada pada material hasil pengecoran. Hasil pengamatan strukturmikro as cast dan as forged pada perbesaran 50x disajikan pada gambar 2 untuk mengamati porositas pada spesimen. Porositas pada spesimen as cast dan as forged masih terlihat, akan tetapi porositas pada spesimen as forged mempunyai intensitas porositas lebih rendah dan ukuran porositas lebih kecil daripada spesimen as cast.

Gambar 3 menunjukkan spesimen dengan proses pendinginan di dapur terbentuk strukturmikro pearlit dan ferit. Pearlit ditunjukkan dengan daerah yang berwarna kelabu dan ferit ditunjukkan dengan daerah yang berwarna terang. Laju pendinginan yang lambat mengakibatkan karbon dapat berdifusi keluar pada saat proses pendinginan dari temperatur austenit stabil, sehingga terbentuklah strukturmikro pearlit dan ferit.
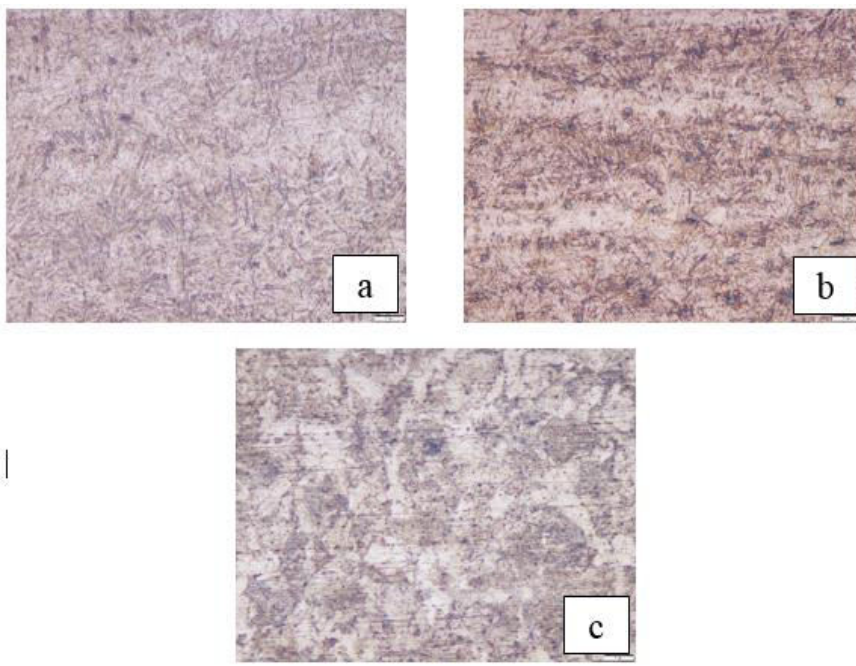

Gambar 3. Hasil pengamatan strukturmikro untuk menentukan fasa yang terbentuk dari proses pendinginan di (a) air, (b) udara,dan (c) dapur.

Pada proses pendinginan di udara, strukturmikro sudah terbentuk martensit. Dimana baja pada umumnya pada saat proses pendinginan di udara akan terjadi strukturmikro perlit dan ferit. Proses pendinginan di air juga didapatkan strukturmikro martensit. Martensit terbentuk dikarenakan pada saat proses pendinginan dari temperatur austenit stabil, karbon tidak mempunyai waktu yang cukup untuk berdifusi keluar dari austenit. Martensit yang terlihat pada proses pendinginan air dan udara adalah lath martensite. Karena baja dengan kadar karbon kurang dari 6\% akan mempunyai martensit dengan bentuk lath sedangkan baja dengan kadar karbon lebih dari $6 \%$ akan mempunyai martensit dengan bentuk plate [2].

Hasil pengamatan strukturmikro pada proses pendinginan di air dan udara, terdapat austenit sisa yang
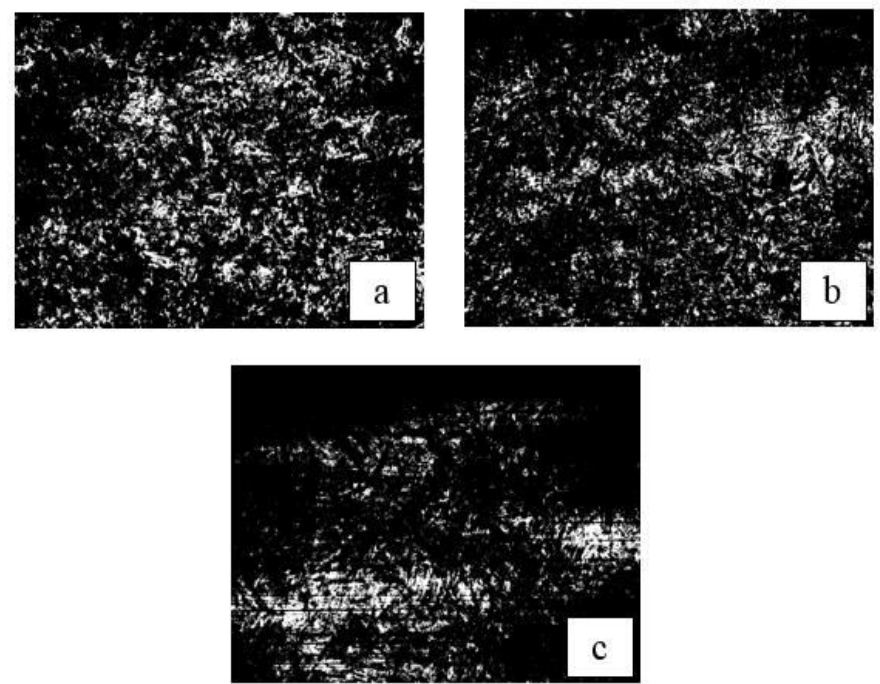

Gambar 4. Hasil image processing strukturmikro proses pendinginan di air untuk menentukan presentase area austenit sisa. Temperatur austenisasi (a) $800{ }^{\circ} \mathrm{C}$, (b) $8500^{\circ} \mathrm{C}$,dan (c) $900{ }^{\circ} \mathrm{C}$.

ditunjukkan dengan daerah yang berwarna terang. Sebagian besar austenit pada baja eutektoid akan berubah menjadi martensit pada saat didinginkan ke temperatur kamar. Bagian yang tidak bertransformasi menjadi martensit ini yang disebut austenit sisa. Untuk mendapatkan struktur 100\% martensit maka diperlukan proses pendinginan lagi sampai dibawah temperatur kamar, proses ini disebut subzero treatment[2].

Tabel 2.

Presentase austenit sisa pada proses pendinginan di air

\begin{tabular}{cc}
\hline \hline Temperatur Austenisasi $\left({ }^{\circ} \mathrm{C}\right)$ & \% Area austenit sisa \\
\hline 800 & 15 \\
850 & 12 \\
900 & 9 \\
\hline \hline
\end{tabular}

Presentase austenit sisa dapat dicari dengan cara mengolah gambar strukturmikro menggunakan image processing software ImageJ yang ditunjukkan oleh gambar 4. Dari gambar strukturmikro spesimen dengan proses pendinginan di air, austenit sisa ditunjukkan dengan daerah yang berwarna putih. Luasan daerah berwarna putih ini kemudian dihitung oleh program dan didapatkan hasil yang disajikan pada tabel 2. Dari tabel 2 dapat disimpulkan bahwa bertambahnya temperatur austenisasi menyebabkan berkurangnya austenit sisa yang ada pada spesimen. Hal ini dikarenakan bahwa pada temperatur austenit $800{ }^{\circ} \mathrm{C}$, austenit memiliki cacat yang disebabkan oleh proses forging. Cacat ini mengakibatkan resistansi pembentukan martensit oleh austenit pada saat proses pendinginan. Akan tetapi dengan menaikkan temperatur austenisasi, cacat di austenit akan berkurang sehingga kemampuan transformasi austenit menjadi martensit 
menjadi lebih baik. Naiknya kemampuan transformasi tersebut membuat bekurangnya austenit sisa [3].

\section{B. Analisa dan Pembahasan Hasil Pengujian Kekerasan}

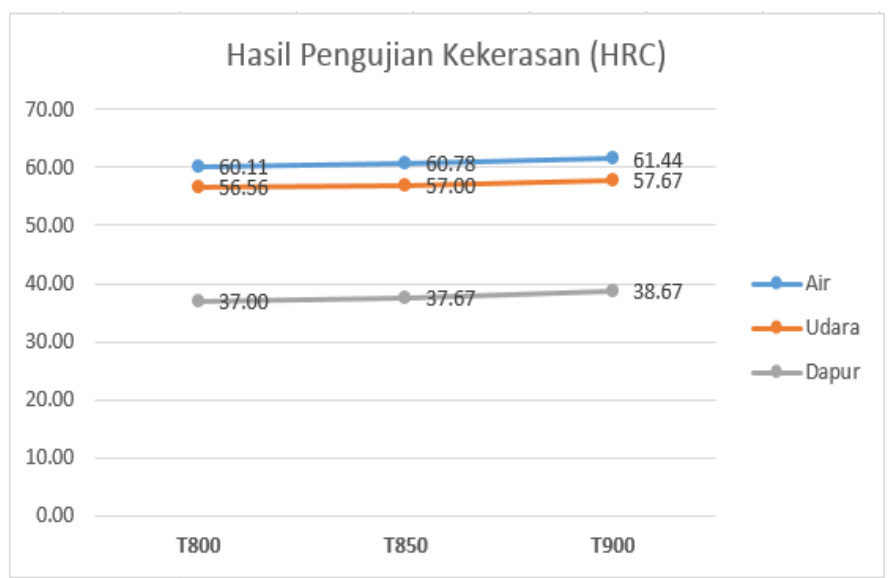

Gambar 5. Grafik hasil pengujian kekerasan pada specimen.

Grafik hasil pengujian kekerasan dapat dilihat pada gambar 5. Dari gambar 5 bisa diambil informasi tentang pengaruh temperatur austenisasi dan proses pendingingan terhadap kekerasan spesimen uji. Grafik tersebut terdapat tiga garis yang masing-masing menunjukkan proses pendinginan air, udara, dan dapur.

Didapatkan nilai kekerasan tertinggi diperoleh proses pendinginan di air, diikuti oleh nilai kekerasan pada proses pendinginan udara, dan nilai kekerasan terkecil didapatkan pada proses pendinginan di dapur. Proses pendinginan mempunyai pengaruh yang sangat besar terhadap kekerasan spesimen. Hal ini dikarekanan laju pendinginan akan mempengaruhi strukturmikro yang terbentuk pada spesimen uji. Laju pendingin pada proses pendinginan di air sangatlah cepat sehingga terbentuk fasa martensit yang mempunyai kekerasan sangat tinggi. Pada sisi lain, proses pendinginan di dapur mengakibatkan terbentuknya fasa pearlit dan ferit yang lebih lunak dibandingkan martensit. Maka dari itu nilai kekerasan paling rendah dimiliki oleh proses pendinginan di dapur.

Jika meninjau hasil pengamatan strukturmikro, proses pendinginan di udara mempunyai strukturmikro yang sama dengan proses pendinginan di air. Akan tetapi nilai kekerasan yang didapat pada proses pendinginan udara sedikit dibawah nilai kekerasan proses pendinginan di air. Berdasarkan diagram CCT dari British Steel 45 MS 6 dan German Steel $0.48 \% \mathrm{C}-1.98 \% \mathrm{Mn}$, diperkirakan kurva pendinginan dari spesimen dengan proses pendinginan udara telah melewati CCR-nya. Strukturmikro yang terbentuk pada proses pendinginan di udara tidak sepenuhnya martensit akan tetapi terbentuk strukturmikro lain seperti ferit, cementit, atau bainit dengan fraksi volume yang kecil. Hal ini membuat kekerasan spesimen pada proses pendinginan udara mempunyai nilai kekerasan sedikit dibawah proses proses pendinginan di air.

Selain proses pendinginan, temperatur austenisasi juga mempengaruhi kekerasan pada spesimen uji. Akan tetapi temperatur austenisasi tidak mempunyai pengaruh yang signifikan terhadap nilai kekerasan spesimen, seperti yang terlihat pada grafik.

\section{Analisa dan Pembahasan Hasil Pengujian Ketangguhan Impak}

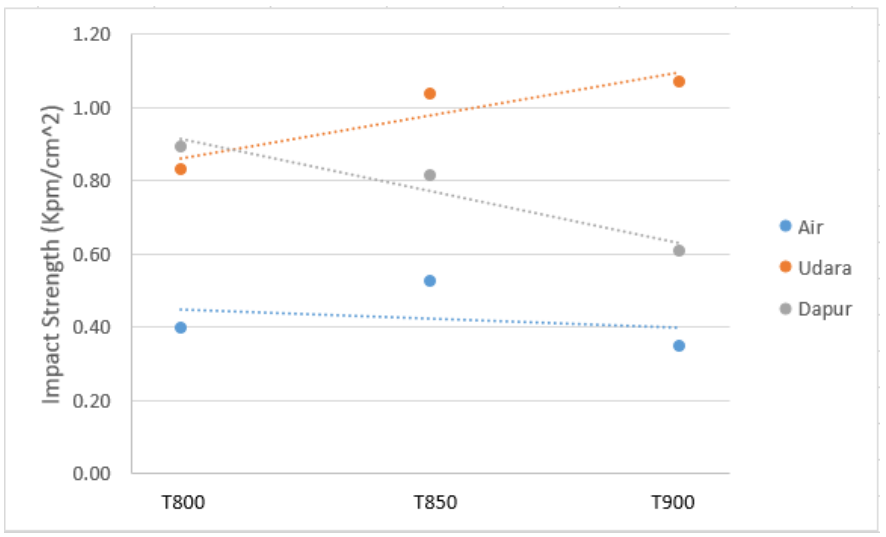

Gambar 6. Grafik impact strength hasil pengujian ketangguhan impak pada specimen.

Grafik yang ditunjukkan pada gambar 6 merupakan grafik yang menunjukkan pengaruh temperatur austenisasi dan proses pendinginan terhadap impact strength. Dari grafik tersebut dapat dilihat bahwa spesimen dengan proses pendinginan di air mempunyai impact strength terendah. Nilai impact strength mengalami kenaikan pada proses pendinginan di dapur. Hal ini disebabkan strukturmikro pada spesimen dengan proses pendinginan dapur adalah perlit dan ferit sedangkan proses pendinginan air mempunyai strukturmikro martensit dan austenit sisa. Ferit dan perlit yang mempunyai sifat mekanik lebih ulet dibandingkan martensit.

Pada proses pendinginan dapur, nilai impact strength mengalami penurunan pada saat temperatur austenisasi dinaikkan. Hal ini disebabkan oleh bertambahnya ukuran butir seiring naiknya temperatur austenisasi yang mengakibatkan turunnya ketangguhan impak dari spesimen. Pada proses pendinginan di air, pengaruh temperatur austenisasi terhadap impact strength cenderung tidak signifikan. Hal ini dikarenakan pengaruh temperatur austenisasi terhadap ketangguhan impak dapat dilihat jika pengujian impak dilakukan pada suhu yang sangat rendah[3].

\section{KESIMPULAN}

Kesimpulan yang didapatkan dari penelitian setelah proses pengambilan dan analisa data adalah :

1. Hasil foto permukaan spesimen awal sebelum ditempat (as cast) dan spesimen setelah tempat (as forged) menunjukkan bahwa intensitas porositas dan ukuran porositas berkurang setelah dilakukan proses penempaan.

2. Strukturmikro martensit pada proses pendinginan di udara sudah terbentuk martensit. Strukturmikro yang didapatkan pada proses pendinginan dapur adalah perlit dan ferit. Sedangkan pendinginan di air didapatkan sturkturmikro martensit dan austenit sisa.

3. Penambahan temperatur austenit mengurangi jumlah austenit sisa yang terbentuk setelah proses pendinginan di air. Didapatkan austenit sisa sebesar 15\% pada temperatur austenisasi $800^{\circ} \mathrm{C}, 12 \%$ pada temperatur 
austenisasi $850^{\circ} \mathrm{C}$, dan $9 \%$ pada temperatur austenisasi $900^{\circ} \mathrm{C}$.

4. Kekerasan tertinggi didapatkan pada proses pendinginan di air, yaitu $60.11\left(800^{\circ} \mathrm{C}\right), 60.78\left(850^{\circ} \mathrm{C}\right)$, dan 61.44 HRC $\left(900^{\circ} \mathrm{C}\right)$. Kekerasan pada proses pendinginan di udara didapatkan $56.56\left(800^{\circ} \mathrm{C}\right), 57\left(850^{\circ} \mathrm{C}\right)$, dan 57.67 HRC $\left(900^{\circ} \mathrm{C}\right)$. Kekerasan terendah pada proses pendinginan di dapur, yaitu $37.00 \quad\left(800^{\circ} \mathrm{C}\right), \quad 37.67$ $\left(850^{\circ} \mathrm{C}\right)$, dan $38.67 \mathrm{HRC}\left(900^{\circ} \mathrm{C}\right)$.

5. Diperoleh nilai impact strength pada spesimen dengan proses pendinginan di air, yaitu $0.35\left(900^{\circ} \mathrm{C}\right), 0.53$ $\left(850^{\circ} \mathrm{C}\right)$, dan $0.4 \mathrm{kpm} / \mathrm{cm}^{2}\left(800^{\circ} \mathrm{C}\right)$. Impact strength pada spesimen dengan proses pendinginan di udara didapatkan $1.07\left(900^{\circ} \mathrm{C}\right), 1.04\left(850^{\circ} \mathrm{C}\right)$, dan $0.99 \mathrm{kpm} / \mathrm{cm}^{2}\left(800^{\circ} \mathrm{C}\right)$. Impact strength pada spesimen dengan proses pendinginan di dapur didapatkan $0.7\left(900^{\circ} \mathrm{C}\right), 0.81$ $\left(850^{\circ} \mathrm{C}\right)$, dan $0.61 \mathrm{kpm} / \mathrm{cm}^{2}\left(800^{\circ} \mathrm{C}\right)$.

\section{DAFTAR PUSTAKA}

[1] T. Sourmail and et al, Novel nanostructured bainitic steel grades to answer the need for high-performance steel components (Nanobain). Luxembourg: European Commission, 2013.

[2] Thelning and Karl-Erik, Steel and Its Heat Treatment. 1984.

[3] H. Hou, "Effect of Austenitizing Temperature On The Mechanical Properties of High-Strength Maraging Steel," Mater. Sci. Eng., vol. 587, pp. 209-212, 2013. 